\title{
Glioma associated microglia/macrophages, a potential pharmacological target to promote antitumor inflammatory immune response in the treatment of glioblastoma
}

\author{
Cinzia Dello Russo ${ }^{1,2}$, Natalia Cappoli ${ }^{1}$ \\ IInstitute of Pharmacology, Università Cattolica del S Cuore, Rome 00168, Italy. \\ ${ }^{2}$ Fondazione Policlinico Gemelli IRCCS, 00168 Rome, Italy.
}

Correspondence to: Dr. Cinzia Dello Russo, Institute of Pharmacology, Università Cattolica del S Cuore, Rome 00168, Italy. E-mail: cinzia.dellorusso@unicatt.it

\begin{abstract}
How to cite this article: Dello Russo C, Cappoli N. Glioma associated microglia/macrophages, a potential pharmacological target to promote antitumor inflammatory immune response in the treatment of glioblastoma. Neuroimmuno/ Neuroinflammation 2018;5:36. http://dx.doi.org/10.20517/2347-8659.2018.42
\end{abstract}

Received: 25 Jun 2018 First Decision: 20 Jul 2018 Revised: 21 Aug 2018 Accepted: 22 Aug 2018 Published: 20 Sep 2018

Science Editor: Athanassios P. Kyritsis Copy Editor: Yuan-Li Wang Production Editor: Huan-Liang Wu

\begin{abstract}
Glioma associated microglia/macrophages (GAMs) constitute the largest proportion of glioma infiltrating cells, particularly in high grade tumors (i.e., glioblastoma). Once inside the tumors, GAMs usually acquire a specific phenotype of activation that favors tumor growth, angiogenesis and promotes the invasion of normal brain parenchyma. Therefore, treatments that limit or prevent GAMs' recruitment at the tumor site or modulate their immune activation promoting antitumor activities are expected to exert beneficial effects in glioblastoma. In the present paper, we aim at the revision of pharmacological strategies that interfere with GAMs' function and are currently proposed as an alternative/additional option to current approved cytotoxic regimens.
\end{abstract}

Keywords: Glioblastoma, macrophages, microglia, metalloproteases, pro-inflammatory activation, pro-tumor functions, glioma associated microglia/macrophages targeted therapies, pharmacotherapy

\section{INTRODUCTION}

Glioma associated microglia/macrophages (GAMs) constitute the largest proportion of tumor infiltrating cells. They are less abundant in low grade gliomas, but constitute up to $30 \%$ of the entire tumor mass in

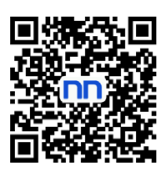




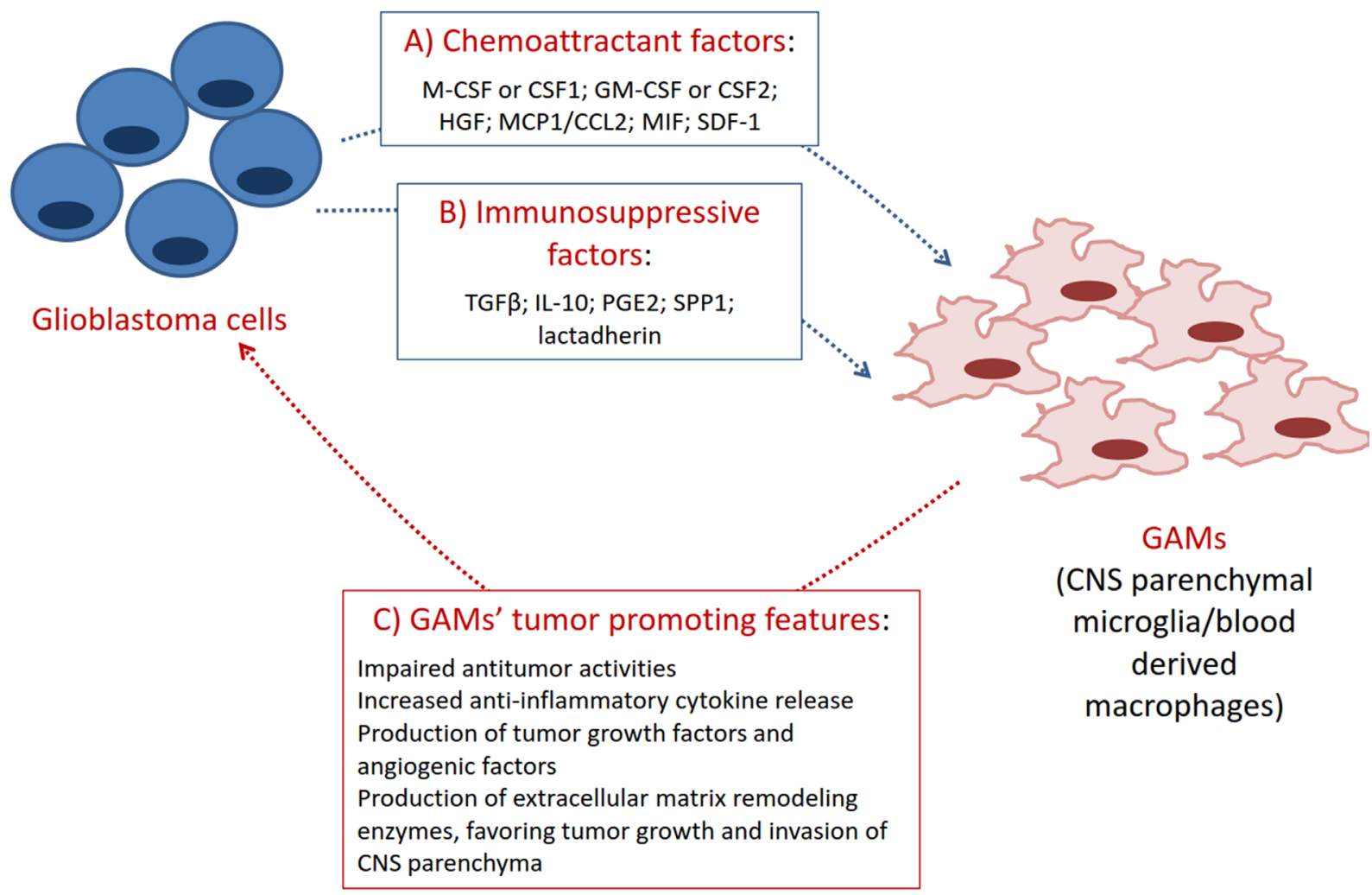

Figure 1. Cross-talk between glioblastoma cells and GAMs. A: Glioblastoma cells produce several chemoattractant factors which promote the recruitment of microglia and macrophages at the tumor site, GAMs; B: once inside the tumor, GAMs are exposed to immunosuppressive/antinflammatory factors and are reprogrammed towards phenotypes that sustain tumor growth, progression and invasion; C: the most relevant tumor promoting features of GAMs are presented. M-CSF: macrophage colony stimulating factor; CSF1: macrophage colony stimulating factor; GM-CSF: granulocyte/macrophage colony stimulating factor; CSF2: granulocyte/macrophage colony stimulating factor; HGF: hepatocyte growth factor; MCP-1/CCL2: monocyte chemotactic protein 1/chemokine (C-C motif) ligand 2; MIF: macrophage inhibitory factor; SDF-1: stromal-derived factor-1; TGF $\beta$ : transforming growth factor $\beta$; IL: interleukin; PGE2: prostaglandin E2; SPP1: osteopontin; GAMs: glioma associated microglia/macrophages; CNS: central nervous system

glioblastoma (IV grade glioma) ${ }^{[1]}$. On the basis of largescale genomic analyses, glioblastoma can be classified into at least four distinct molecular subtypes ${ }^{[2]}$, among which the mesenchymal subtype tends to have the most relevant immune component ${ }^{[3]}$. Microglial cells, scattered in normal brain parenchyma, are recruited at the tumor site by glioblastoma-secreted chemoattractant factors ${ }^{[4,5]}$ [Figure 1], while peripheral bloodderived macrophages, normally found in the perivascular space, meninx and choroid plexus, accumulate in glioblastoma trough breakdown of the blood-brain-barrier $(\mathrm{BBB})^{[1]}$ particularly in high grade glioma ${ }^{[6]}$. Iba $1^{+}$cells were consistently detected in a group of 41 glioblastoma specimens, showing preferentially an amoeboid phenotype toward the tumor center and a ramified morphology in the periphery of the tumors ${ }^{[7]}$. In addition, markers suggesting both pro- and anti-tumoral properties of GAMs were detected. A significant proportion of cells expressing the cluster of differentiation (CD) 163 and the inducible nitric oxide synthase (iNOS) was found in the tumor parenchyma together with a wider distribution of arginase 1 positive cells ${ }^{[7]}$. GAMs are frequently detected in the perivascular niche of tumor blood vessels, and their number increases with tumor progression ${ }^{[8]}$. As shown in Figure 1, invading microglia/macrophages play a critical role in the regulation of glioma biology, including tumor growth, progression and invasion ${ }^{[8]}$. Consistently, depletion of microglia/macrophages in vivo experimental models significantly reduced tumor growth ${ }^{[8-12]}$, holding the potential to ameliorate the outcome of current available therapies.

In this regard, standard treatment for glioblastoma includes maximal surgical resection (whenever feasible), followed by radiotherapy and concurrent treatment with temozolomide plus additional 6 cycles of adjuvant temozolomide ${ }^{[13]}$. Despite such multimodal approach, the average survival of patients diagnosed with glioblastoma remains low (14-16 months), with better outcomes observed when tumors display $\mathrm{O}^{6}$-methylguanine 
DNA-methyltransferase promoter methylation ${ }^{[13]}$. In fact, most glioblastoma tumors tend to recur after being surgically removed. This is partly due to the highly infiltrative nature of these cancer cells, so that radical surgery is difficult to achieve. On the other hand, tumors can regenerate from glioblastoma cancer stem cells (GSCs) that are usually resistant to radio- and chemotherapy. Treatment guidelines for recurrent disease are less defined and may include a second surgery, re-irradiation, or re-exposure to temozolomide at standard dose. Other options comprise systemic chemotherapy with one nitrosourea drug, i.e., carmustine, lomustine, or fotemustine, and in the United States, the monoclonal antibody against vascular endothelial growth factor-A (VEGF-A) bevacizumab ${ }^{[13]}$. Finally, several targeted therapies have been tested in clinical trials with limited beneficial effects. Interestingly, we observed using primary cultures of rat microglial cells that temozolomide did not reduce microglial cell viability after $24 \mathrm{~h}$ treatments in the $\mu \mathrm{mol} / \mathrm{L}$ (clinically relevant) dose range, albeit it significantly increased intracellular protein content ${ }^{[14]}$. Notably, resistance to anti-angiogenic therapy, i.e., bevacizumab, appears to be mediated by changes in the glioblastoma's microenvironment, including the extent of myeloid cell infiltration as well as their biological activities ${ }^{[15-17]}$. In preclinical models of glioblastoma, it has been shown that ionizing radiations increase the recruitment of myeloid cells with a protumorigenic phenotype at the tumor site, contributing to disease recurrence ${ }^{[18]}$. Taken together, the evidence suggest a possible involvement of GAMs in the response to standard treatments. Therefore, glioma associated myeloid cells can be envisioned as an alternative or an ancillary pharmacological target to improve the clinical outcome of current available therapies. Noteworthy, the glioblastoma microenvironment includes also other immune cells, namely regulatory T cells (Tregs) and myeloid-derived suppressor cells (MDSCs), that concur to the establishment of an immunosuppressive environment, impairing the effector function of infiltrating $\mathrm{T}$ cells and natural killer cells and facilitating tumor growth ${ }^{[19]}$. Therefore, a comprehensive understanding of these different components of the patients' immune system endowed in the tumor microenvironment is necessary to develop therapeutic strategies that increase anti-tumor immunity and clinical benefits. In the present paper, we aim at the revision of pharmacological strategies that interfere with GAMs' function, i.e., cell recruitment at the tumor site, cell inflammatory activation and immune function, and the extracellular matrix remodeling promoted by GAM-secreted factors. For recent advances on the biology of MDSCs and Tregs in the glioblastoma microenvironment and their potential role as therapeutic targets, we refer the readers to other review articles ${ }^{[20,21]}$.

\section{DRUGS TARGETING GAMS' FUNCTION FOR THE TREATMENT OF GLIOBLASTOMA}

\section{Drugs that interfere with GAMs' recruitment at the tumor site}

Microglial cells are recruited at the tumor site by several chemoattractant factors which are produced and released by tumoral cells ${ }^{[4,5]}$. One of the first identified GAMs' chemoattractant factor is the hepatocyte growth factor ${ }^{[22]}$, which binds to and activates the tyrosine kinase receptor, c-Met. The latter plays a role both on microglial motility and cell proliferation ${ }^{[22]}$. Other glioma-released chemoattractant factors are the myeloid colony stimulating factors (CSFs), i.e., the macrophage colony stimulating factor (M-CSF or CSF1 ${ }^{[23]}$, the granulocyte/macrophage colony stimulating factor (GM-CSF or CSF 2$)^{[24]}$. These factors signal through activation of two different receptors ${ }^{[25]}$. The M-CSF receptor (CSF1R) is a homodimeric type III receptor, encoded by the FMS proto-oncogene, with intrinsic tyrosine kinase activity, whereas the GM-CSF receptor (CSF2R) is a heterodimer composed of a specific ligand-binding subunit (the $\alpha$-chain) and a common $\beta$-chain. The latter is the signal transduction subunit and is shared with the receptors for interleukin (IL)-3 and IL5. Activation of the CSF2 R is known to stimulate at least three pathways: the Janus kinase-signal transducer and activator of transcription (JAK-STAT) pathway, the mitogen-activated protein kinase (MAPK) pathway and the phosphoinositide 3-kinase pathway ${ }^{[25]}$. In addition, the monocyte chemotactic proteins (MCPs), particularly MCP-1/chemokine (C-C motif) ligand $2(\mathrm{CCL} 2)^{[26,27]}$, and the stromal-derived factor-1 (SDF-1) ${ }^{[28]}$, have shown to play a role in the recruitment of microglial cells to the tumor site [Figure 1]. In addition a substantial number of peripherally derived macrophages can be consistently detected in glioma GL261 implanted tumors, since the early phases of disease ${ }^{[29]}$. Once inside the tumors, GAMs usually acquire a specific phenotype of activation ${ }^{[30]}$ that favors tumor growth, angiogenesis and promotes the invasion of normal brain pa- 
renchyma $^{[5]}$. Therefore, pharmacological treatments that prevent or reduce GAMs' recruitment at the tumor site are expected to exert beneficial effects in glioblastoma. In this regard, it has been shown that the immunosuppressant agent cyclosporine A (CsA), a drug normally used in clinical practice, significantly reduces the number of infiltrating microglia/macrophages in implanted glioma tumors. This effect, together with a modulation of GAM's inflammatory activation, results in a significant reduction of tumor growth ${ }^{[9]}$. However, chronic immunosuppression associated with systemic use of CsA increases the risk of developing tumors, and may probably limit the use of this drug for the treatment of glioblastoma. In addition, several tumor favoring mechanisms are associated with CsA, including increased production of transforming growth factor $\beta$ (TGF $\beta$ ) and VEGF together with an inhibitory action on the DNA repairing ability of the cells ${ }^{[31]}$. In the human U-87 glioma cell line, CsA significantly reduced the expression level of the human microRNA (miRNA, miR-)195, together with the modulation of several other miRNAs ${ }^{[32]}$. Interestingly, miR-195 seems to play a tumor suppressor function in both glioma cell lines and human gliomas ${ }^{[33,34]}$. On the other hand, the nuclear factor of activated T cells (NFAT1), i.e., the main intracellular target of CsA, appears to be a crucial regulator of glioma invasion-related genes. Thus, a direct inhibition of NFAT1 activity in glioma cells can limit their ability to infiltrate normal brain parenchyma, and may be considered as a potential adjuvant therapy for glioblastoma ${ }^{[35]}$.

Interestingly, novel compounds, interfering with known chemoattractant factors, are in different stages of development for the treatment of glioblastoma. For example, it has been shown that the CSF-1R inhibitor BLZ945, which blocks the signaling pathways activated by M-CSF, significantly increased survival in different preclinical models of glioblastoma ${ }^{[36]}$. This pharmacological treatment induced the regression of established tumors in engineered mice and abated tumor growth in human xenografts. The drug is a small molecular weight CSF-1R inhibitor, with optimal BBB penetration properties. However, despite the chemoattractant properties of M-CSF and its established role in promoting macrophage survival, BLZ945 did not reduce the number of tumor infiltrating microglia/macrophages in these models. GAMs appeared indeed protected from BLZ-induced cell death by glioma-secreted cytokines such as GM-CSF, interferon $\gamma$ (IFN $\gamma$ ) and the C-X-C motif chemokine 10 (CXCL10) ${ }^{[36]}$. On the other hand, BLZ945 modulated the inflammatory activation of GAMs, favoring their antitumor activities which explains the beneficial effects observed with the treatment (see next section). In a different preclinical model of glioblastoma, consisting of tumors derived by implantation of GSCs lacking tumor suppressor phosphatase and tensin homolog, p53 and neurofibromin 1 (NF1), BLZ945 efficiently blocked GAMs' recruitment at tumor site together with reducing tumor growth $^{[37]}$. Interestingly, a first-in-human study employing BLZ945 (NCT02829723) is currently ongoing. It is a phase I/II with BLZ945 given as a single agent or in combination with PDR001 [a novel monoclonal antibody against the immune checkpoint programmed death-1 (PD-1) receptor, by Novartis Oncology], which aims at the characterization of the safety, tolerability, pharmacokinetics, pharmacodynamics, and antitumor activity of BLZ945 in adult patients with advanced solid tumors. Moreover, another selective CSF$1 \mathrm{R}$ inhibitor (PLX3397) has been recently tested in a phase II clinical trial in patients affected by recurrent glioblastoma (NCT01349036). The drug was well tolerated, showed good BBB penetration, and reduced the amount of $\mathrm{Ibar}^{+}$cells within the tumors. However, no significant improvement in the progression free survival compared with historical controls was observed in PLX3397 treated patients ${ }^{[38]}$. Moreover, it has been recently shown that genetic reduction of MCP-1/CCL2 significantly reduces macrophage infiltration within the tumors extending the survival time of tumor bearing animals ${ }^{[39]}$. However, previous attempts to block MCP-1/CCL2 with monoclonal antibodies demonstrated modest clinical efficacy. The drugs were instead effective in combination with temozolomide, significantly increasing mice survival ${ }^{[27]}$. Interestingly, it has been shown that the production of MCP-1 by glioma cells can be efficiently reduced by non-cytotoxic drugs, including the antibiotic minocycline, the angiotensin II receptor inhibitor telmisartan and the bisphosphonate zolendronic $\operatorname{acid}^{[40]}$. These drugs have a good BBB penetration and will be tested in combination as an ancillary therapy to improve the outcome of currently approved cytotoxic regimens.

Recently, a small molecular weight inhibitor of the AXL receptor tyrosine kinase has been shown to exert 
relevant antiproliferative effects on different preclinical models of glioblastoma. The drug, namely BGB324 (also known as R428) significantly increased neurological free survival particularly in the group of mice bearing high-AXL expressing tumors ${ }^{[37]}$. In addition, BGB324 treatment reduced the amount of infiltrating $\mathrm{CD}_{4}{ }^{+}$leukocytes and $\mathrm{CD} 11 \mathrm{~b}^{+}$GAMs. Interestingly, the anti PD-1 inhibitor nivolumab increased the protective effects of BG324, and effectively prolonged the survival of tumor bearing mice ${ }^{[37]}$. Nivolumab per se displayed no survival benefits in these animals, while increasing both AXL kinase activity and GAMs' tumor infiltration. In line with these observations, a phase III clinical trial (NCT02017717) set to compare the efficacy and safety of nivolumab administered alone versus bevacizumab in patients diagnosed with recurrent glioblastoma failed to demonstrate its efficacy ${ }^{[19]}$. Immune PD-1 check point inhibitors, including nivolumab, have proven efficacy in various malignancies and the number of clinical approved indications is constantly increasing $^{[41]}$. The use of these drugs is associated with specific toxicities, often termed immune-related adverse events. The most common side effects involve the skin, colon, endocrine organs and liver. Rarely, neurological complications have been described ${ }^{[41]}$, including recent case reports on nivolumab-induced autoimmune encephalitis ${ }^{[42]}$ and progressive multifocal leukoencephalopathy ${ }^{[33]}$.

Finally, microglial/macrophages' infiltration of GSC-derived tumors was efficiently blocked by the integrin inhibitor arginine-glycine-aspartic acid (RGD) peptides albeit interfering with GSC-secreted periostin ${ }^{[44]}$. Consistently, genetic ablation of periostin reduced GAMs' recruitment at tumor site and modulated their immune functions, thus inhibiting tumor growth and increasing survival of glioma bearing animals. Similar beneficial effects were expected by pharmacological inhibition of integrin signaling pathways in human glioblastoma. However, despite promising phase I/II results, a recent phase III clinical trial failed to demonstrate clinical efficacy of cilengitide, a cyclic RGD pentapeptide that selectively inhibits the av $\beta 3$ and av $\beta 5$ integrins when added to standard temozolomide treatment in glioblastoma patients ${ }^{[45]}$. A possible explanation for these negative findings can be retrieved in part in the unfavorable pharmacokinetic profile of cilengitide ${ }^{[46]}$. In fact, the relevance of the signaling pathways downstream the integrin receptors, $\alpha v \beta 3$ and $\alpha \mathrm{v} \beta 5$, is further supported by a recent proteomic analysis of the glioma secretome. These data suggest the involvement of osteopontin (SPP1) and lactadherin in the reprogramming of GAMs' immune responses towards pro-tumoral functions via integrin signaling ${ }^{[47]}$.

\section{Drugs that interfere with GAMs' inflammatory activation and immune function}

Under the influence of glioma cells, the antitumor functions of GAMs appear mostly suppressed. As shown in Figure 1, tumor cells indeed produce several immunosuppressive molecules, such as TGF $\beta$, IL-10, and various prostaglandins (i.e., prostaglandin E2, PGE2), thus favoring the acquisition of a pro-tumorigenic phenotype of activation by GAMs ${ }^{[30,48,49]}$. Pharmacological strategies that promote antitumor activities of GAMs, i.e., production of cytotoxic molecules and increased phagocytosis, or that reduce the release of protumorigenic (i.e., growth factors) may exert beneficial effects in glioblastoma. In this regard, amphotericin $\mathrm{B}(\mathrm{AmpB})$, an antifungal compound clinically used to treat life-threatening fungal infections ${ }^{[50]}$, has been shown to promote macrophage activation via toll like receptor activation and increase pro-inflammatory cytokine release $^{[51]}$. In view of these properties, $\mathrm{AmpB}$ was recently tested in preclinical models of gliomas. In an experimental model consisting of human-derived GSC tumors implanted in nonobese diabetic/severe combined immunodeficiency (NOD-SCID) mice, systemic administration of AmpB significantly reduced tumor growth and increased animal survival ${ }^{[52]}$. The drug did not exert direct anti-tumor activity on GSCs in vitro and its pharmacological benefits in vivo were abated by depletion of myeloid cells. This suggests that the beneficial effects of AmpB were mediated by modulation of GAMs' functions. Increased tumor infiltration of $\mathrm{Ibar}^{+}$microglial cells and macrophages was detected in AmpB treated animals. This effects has been recently confirmed using ultrasmall iron oxide nanoparticles as contrast agents for magnetic resonance imaging, in order to detect monocyte infiltration into brain tumors ${ }^{[53]}$. In addition, tumor infiltrating $\mathrm{Iba}^{+}$cells in response to AmpB showed a significant up-regulation of iNOS, that most likely results in increased production of cytotoxic nitric oxide $(\mathrm{NO})^{[52]}$ Beneficial effects of AmpB were also observed in immunocompe- 
tent $\mathrm{C} 57 \mathrm{BL} / 6$ mice, against highly aggressive tumors derived from enriched stem-like CD133 ${ }^{+}$GL261 glioma cells. Notably, the antitumor effects of $\mathrm{AmpB}$ in vivo are achieved with lower doses than those maximally tolerated in humans.

Another promising class of therapeutics for the treatment of glioblastoma are the inhibitors of the mechanistic target of rapamycin (mTOR) kinase and/or other related kinases. The mTOR kinase is a central regulator of several intracellular processes related to cellular growth, metabolism, and proliferation ${ }^{[54]}$. Robust evidence have highlighted the crucial role of this pathway in glioblastoma biology, together with the demonstration of significant antiproliferative effects obtained by its pharmacological inhibition ${ }^{[55]}$. Several drugs targeting this activity are currently in clinical development for the treatment of different types of cancer ${ }^{[56]}$, including those with an optimal pharmacokinetic profile for the treatment of glioblastoma ${ }^{[56,57]}$. Notably, we have shown that inhibition of mTOR activity in rat microglial cells can promote their antitumor properties while restricting pro-tumorigenic features ${ }^{[58]}$. Therefore, mTOR inhibitors have the potential to target both glioblastoma and GAMs' functions. Similarly, the chemokine receptor C-C chemokine receptor type 5 (CCR5) inhibitor maraviroc, in the same in vitro model, showed both direct antiproliferative activities on rat glioma C6 cells together with immune modulatory actions on glioma stimulated rat microglial cultures ${ }^{[59]}$.

Interestingly, both glioma and infiltrating GAMs express the $\mathrm{Ca}^{2+}$-activated $\mathrm{K}^{+}$channels (KCa3.1), whose inhibition using 1-(2-chlorophenyl) diphenylmethyl-1H-pyrazole (TRAM-34) induced a switch of GAMs toward a pro-inflammatory, antitumor phenotype ${ }^{[60]}$. In addition, in vivo treatments with TRAM-34 significantly decreased the extent of tumor growth in glioma-bearing mice ${ }^{[60]}$. Moreover, stimulation of microglia with pro-inflammatory IL-12 is associated with increased phagocytic activity ${ }^{[6]}$. Consistently, intracranial injection of a recombinant adeno-associated viral vector (rAAV2) encoding for IL-12 augmented the brain levels of IL-12 and IFN $\gamma$ in tumor-bearing animals, favoring microglial infiltration into the tumor and restoring their antitumor functions. Increased immune activation of GAMs significantly reduced tumor growth and prolonged animal survival time ${ }^{[62]}$. Similarly, systemic administration of miR-142-6p, whose expression level is consistently downregulated in GAMs, extended animal survival in different glioma models. These beneficial effects relied on reduced GAMs' infiltration at the tumor site and increased antitumor activities $^{[63]}$. Inhibition of the C-X-C chemokine receptor type 4 (CXCR4) by a newly synthetized receptor antagonist, peptide R, reduced tumor growth, glioma cell invasiveness, and intratumor vessel formation while directing GAMs' immune activation toward a pro-inflammatory/antitumor phenotype ${ }^{[64]}$. Notably, SDF-1 suppression in a murine glioma resulted in delayed tumor growth and invasiveness, lower microvascular density, and higher density of microglia/macrophages in non-hypoxic compared to hypoxic regions. These findings suggest that tumor-secreted SDF-1 stimulates glioma invasiveness and recruitment of GAMs towards hypoxic areas ${ }^{[65]}$. In addition, it has been recently shown that the antitumor activity of vosaroxin, a first in class cytotoxic agent that intercalates DNA and inhibits topoisomerase II, are also linked to increased recruitment of myeloid cells at the tumor site together with an augmented pro-inflammatory activation ${ }^{[6]]}$. Likewise, the antitumor effects of chlorogenic acid (5-caffeoylquinic acid) (CHA) found in pre-clinical models of glioblastoma were associated with increased antitumor immune activations of GAMs. CHA is phenolic compound found in the human diet, in coffee, apples, pears and in green tea ${ }^{[67]}$. Finally, a recent paper describes the beneficial effects of a single chain antibody (X7Ab) directed against the chemokine receptor ACKR3/CXCR7. Reduction of tumor growth and improved survival were observed in vivo in different preclinical models of glioblastoma, particularly when X7Ab was used in combination with standard doses of temozolomide. Interestingly, increased mean fluorescence intensity of classical activated (major histocompatibility complex class II, MHCII') tumor infiltrating macrophages was detected, suggesting augmented proinflammatory (i.e., antitumor) activation of these cells within the tumor microenvironment ${ }^{[68]}$.

\section{Drugs that interfere with matrix remodeling promoted by GAM-secreted factors}

Besides their immune functions which may either restrict or favor astrocyte malignant transformation, 
GAMs are directly involved in the degradation of the extracellular matrix. Thus, these cells are key regulators of a central process involved in the expansion of tumors as well as in the invasion of normal brain parenchyma ${ }^{[69]}$. In fact, microglial cells significantly increase the invasive phenotype of GL261 glioma cells in $v i v{ }^{[70]}$. Consistently, the invasiveness of glioma cells is diminished in microglial-depleted organotypic brain slices inoculated with GL261 glioma cells ${ }^{[71]}$. Matrix metalloproteases (MMPs), i.e., the enzymes involved in the remodeling of the extracellular environment ${ }^{[72]}$, are largely produced by tumor cells, infiltrating microglia/macrophages, or other infiltrating leukocytes, particularly at the invasive tumor edge facilitating tumor growth and invasion ${ }^{[7,73,74]}$. As detailed in our recent review ${ }^{[4]}$, a complex crosstalk exists between glioma cells and infiltrating GAMs which increases the activity of MMP enzymes, including MMP-2 and MMP-9. Notably, the latter is over-expressed in GAM cells sorted from human glioblastoma tissues ${ }^{[75]}$.

Consistently, several pharmacological treatments displayed beneficial effects in glioblastoma by limiting the release of MMPs. For example, minocycline, a highly lipophilic tetracycline antibiotic with a good BBB penetration property, reduced the expression of MT1-MPP in invading microglia/macrophages by suppressing p38 MAPK activation ${ }^{[76]}$. The drug also reduced secretion of MMP- $9^{[75]}$ and other pro-inflammatory cytokines from microglia and tumor cells resulting in an overall decrease of glioblastoma cell migration ${ }^{[76]}$. Notably, minocycline is also able to reduce MCP-1 secretion by glioblastoma cells, thus potentially limiting GAMs' recruitment at tumor site (as discussed above). The same inhibitory effects on MT1-MMP were displayed in vitro by the lipid lowering agent, atorvastatin ${ }^{[77]}$. In addition, propentofylline, an atypical methylxanthine with central nervous system (CNS) glial modulating and antinflammatory actions, significantly reduced tumor growth by targeting microglial production of MMP-9. The drug restricted also the migratory capacity of both glioma CNS-1 cells and microglia in vitro ${ }^{[78]}$. Invasion and infiltration of the normal brain parenchyma interfere with radical surgical resections of glioblastoma, that often recur after the first aggressive treatment. Pharmacological reduction of glioma cell motility and invasiveness thus hold the potential to improve the outcome of current therapeutic approaches, by limiting the infiltration extent of normal brain parenchyma ${ }^{[69]}$.

\section{Other features of GAMs}

In vitro, microglia co-cultured in the presence of glioma cells appear to be morphologically activated although phagocytosis is largely impaired ${ }^{[10]}$. Nevertheless, another promising therapeutic approach for the treatment of glioblastoma consists in the use of nanoparticles which are internalized by GAMs increasing their antitumor immune activation ${ }^{[79,80]}$. Moreover, GAMs produce a vast array of growth and angiogenic factors which further sustain proliferation of tumor cells ${ }^{[8,48,52]}$ as well as tumor vessel formation ${ }^{[81]}$. Interestingly, genetic and pharmacological ablation in GAMs of neuropilin 1, a co-receptor that amplifies signaling through the VEGF-A and TGF $\beta$ pathways, is associated with reduced glioma growth and blood vessel formation and increased survival time of glioma bearing mice ${ }^{[82]}$.

\section{CONCLUSION}

GAMs represent the most relevant population of tumor infiltrating cells that significantly contribute to the pathogenesis of glioblastoma by favoring tumor growth and invasion of the normal brain parenchyma. Preclinical evidence supports the notion that GAMs are a viable pharmacological target whose function can be modulated in order to prevent their pathological activation. Current available data, summarized in Table 1, suggest that the immune activation of GAMs can be genetically or pharmacologically modulated so that these cells can be efficiently instructed to perform anti-tumor activities. In addition, it is possible to control their recruitment at the tumor site, and the production of extracellular matrix remodeling enzymes, thus limiting tumor growth and the ability to infiltrate normal brain parenchyma. One of the main limitations to systemic chemotherapy for glioblastoma is represented by the inability of most drugs to effectively penetrate the $\mathrm{BBB}$ and achieve cytotoxic concentrations in the cerebrospinal fluid and brain parenchyma. In fact, sev- 
Table 1. Drugs targeting GAMs' functions within the glioblastoma microenvironment

\begin{tabular}{|c|c|c|c|c|c|c|}
\hline $\begin{array}{l}\text { Drug name and approval } \\
\text { status }\end{array}$ & Drug properties & $\begin{array}{c}\text { Molecular } \\
\text { target }\end{array}$ & $\begin{array}{l}\text { Pharmacological } \\
\text { actions on GAMs }\end{array}$ & Other effects & Clinical outcome & Ref. \\
\hline \multicolumn{7}{|l|}{ Preclinical evidence } \\
\hline $\begin{array}{l}\text { Amphotericin B } \\
\text { Approved for clinical use } \\
\text { by FDA and in EU mem- } \\
\text { ber states }\end{array}$ & Small MW compound & $\begin{array}{l}\text { Toll-like recep- } \\
\text { tors }\end{array}$ & $\begin{array}{l}\uparrow \text { GAM's tumor } \\
\text { infiltration } \\
\uparrow \text { GAMs' antitumor } \\
\text { immune activation } \\
\uparrow \text { iNOS expression } \\
\text { and NO production }\end{array}$ & $\begin{array}{l}\text { No direct antipro- } \\
\text { liferative effects on } \\
\text { GSCs in vitro }\end{array}$ & $\begin{array}{l}\downarrow \text { Tumor growth } \\
\uparrow \text { Survival }\end{array}$ & {$[52,53]$} \\
\hline $\begin{array}{l}\text { Cyclosporine A } \\
\text { Approved for clinical use } \\
\text { by FDA and in EU mem- } \\
\text { ber states }\end{array}$ & Small MW compound & $\begin{array}{l}\text { Calcineurin/ } \\
\text { NFAT1 }\end{array}$ & $\begin{array}{l}\downarrow \text { GAMs' tumor } \\
\text { infiltration } \\
\downarrow \text { IL10, ARG1 and } \\
\text { GM-CSF } \\
\downarrow \text { MMP2 }\end{array}$ & $\begin{array}{l}\uparrow \mathrm{TGF} \beta \text { and } V E G F \\
\downarrow \text { DNA repair } \\
\downarrow \text { miR195 and other } \\
\text { miRNAs }\end{array}$ & $\begin{array}{l}\downarrow \text { Tumor growth } \\
\text { Potential tumor } \\
\text { promoting activities }\end{array}$ & {$[9,31,32]$} \\
\hline $\begin{array}{l}\text { Minocycline } \\
\text { Approved for clinical use } \\
\text { by FDA and in EU mem- } \\
\text { ber states }\end{array}$ & Small MW compound & p38-MAPK & $\begin{array}{l}\downarrow \text { MT1-MPP, } \downarrow \text { MMP- } \\
9 \text { production by } \\
\text { GAMs } \\
\downarrow \text { Tumor cells' migra- } \\
\text { tion }\end{array}$ & $\begin{array}{l}\downarrow \text { Pro-inflammary cy- } \\
\text { tokines by microglia } \\
\downarrow \text { MCP- } 1 \text { by glioma } \\
\text { cells }\end{array}$ & $\begin{array}{l}\downarrow \text { Tumor growth } \\
\uparrow \text { Survival }\end{array}$ & {$[40,75,76]$} \\
\hline $\begin{array}{l}\text { Nivolumab } \\
\text { Approved for clinical use } \\
\text { by FDA and EMA }\end{array}$ & $\begin{array}{l}\text { Biologic } \\
(\mathrm{mAb})\end{array}$ & PD-1 & $\begin{array}{l}\uparrow \mathrm{GAMs} \text { ' tumor } \\
\text { infiltration } \\
\uparrow \mathrm{AXL} \text { kinase activity }\end{array}$ & $\begin{array}{l}\uparrow \text { Protective effects } \\
\text { of BG324 }\end{array}$ & $\begin{array}{l}\text { No survival benefits } \\
\text { perse }\end{array}$ & [37] \\
\hline $\begin{array}{l}\text { mTOR kinase } \\
\text { inhibitors } \\
\text { Approved/ } \\
\text { investigational drugs }\end{array}$ & Small MW compound & mTOR kinase & $\begin{array}{l}\uparrow \text { Pro-inflammatory } \\
\text { activation of microg- } \\
\text { lia in vitro }\end{array}$ & $\begin{array}{l}\text { Direct antiprolifera- } \\
\text { tive effects }\end{array}$ & $\downarrow$ Tumor growth & {$[55,57,58]$} \\
\hline $\begin{array}{l}\text { BGB324 } \\
\text { (R428) } \\
\text { Investigational }\end{array}$ & Small MW compound & $\begin{array}{l}\text { Receptor tyro- } \\
\text { sine kinase AXL }\end{array}$ & $\begin{array}{l}\downarrow C D 11 b+\text { GAMs' } \\
\text { tumor infiltration } \\
\downarrow \text { CD45+ leukocyte } \\
\text { tumor infiltration }\end{array}$ & & $\uparrow$ Survival & [37] \\
\hline $\begin{array}{l}\text { BLZ945 } \\
\text { Investigational }\end{array}$ & Small MW compound & CSF-1R & $\begin{array}{l}\uparrow \text { survival of GAMs } \\
\uparrow \text { GAMs' phagocytic } \\
\text { activity } \\
\downarrow \text { GAMs' protumor } \\
\text { immune activation }\end{array}$ & $\begin{array}{l}\uparrow / \downarrow \text { GAMs' tumor } \\
\text { infiltration }\end{array}$ & $\begin{array}{l}\downarrow \text { Tumor growth } \\
\uparrow \text { Survival }\end{array}$ & {$[36,37]$} \\
\hline $\begin{array}{l}\text { CHA } \\
\text { Investigational }\end{array}$ & Small MW compound & $\begin{array}{l}\text { STAT } \\
\text { factors }\end{array}$ & $\begin{array}{l}\uparrow \mathrm{GAMs}^{\prime} \text { antitumor } \\
\text { immune activation }\end{array}$ & & $\downarrow$ Tumor growth & {$[67]$} \\
\hline $\begin{array}{l}\text { Propentofylline } \\
\text { Investigational }\end{array}$ & Small MW compound & $\begin{array}{l}\text { Phosphor- } \\
\text { diesterase }\end{array}$ & $\downarrow$ MMP-9 by GAMs & $\begin{array}{l}\downarrow \text { Migratory capac- } \\
\text { ity of microglia and } \\
\text { glioma }\end{array}$ & $\downarrow$ Tumor growth & {$[78]$} \\
\hline $\begin{array}{l}\text { TRAM-34 } \\
\text { Investigational }\end{array}$ & Small MW compound & KCa3.1 channels & $\begin{array}{l}\uparrow \mathrm{GAMs} \text { antitumor } \\
\text { immune activation }\end{array}$ & & $\downarrow$ Tumor growth & {$[60]$} \\
\hline $\begin{array}{l}\text { Vosaroxin } \\
\text { Investigational }\end{array}$ & Small MW compound & $\begin{array}{l}\text { DNA and } \\
\text { TOPO-II }\end{array}$ & $\begin{array}{l}\uparrow \mathrm{GAMs} \text { tumor } \\
\text { infiltration } \\
\uparrow \mathrm{GAMs} \text { antitumor } \\
\text { immune activation }\end{array}$ & & $\downarrow$ Tumor growth & {$[66]$} \\
\hline $\begin{array}{l}\text { Peptide } \mathbf{R} \\
\text { Investigational }\end{array}$ & Synthetic peptide & CXCR4 & $\begin{array}{l}\uparrow \text { GAMs' antitumor } \\
\text { immune activation }\end{array}$ & $\begin{array}{l}\downarrow \text { Glioma invasive- } \\
\text { ness, } \\
\downarrow \text { Intratumor vessel } \\
\text { formation }\end{array}$ & $\downarrow$ Tumor growth & {$[64]$} \\
\hline $\begin{array}{l}\text { RGD peptides } \\
\text { Investigational }\end{array}$ & Synthetic peptides & Integrins & $\begin{array}{l}\downarrow \text { GAMs' tumor } \\
\text { infiltration } \\
\uparrow \text { GAMs' antitumor } \\
\text { immune activation }\end{array}$ & $\begin{array}{l}\downarrow \text { GSC-secreted } \\
\text { periostin }\end{array}$ & $\downarrow$ Tumor growth & {$[44]$} \\
\hline $\begin{array}{l}\text { IL-12 or } \\
\text { rAAV2-mediated IL-12 } \\
\text { Investigational }\end{array}$ & $\begin{array}{l}\text { Biologic } \\
\text { (protein or engineered } \\
\text { viral vector) }\end{array}$ & IL-12 receptor & $\begin{array}{l}\uparrow \text { GAMs' tumor } \\
\text { infiltration } \\
\uparrow \text { GAMs' antitumor } \\
\text { immune activation } \\
\uparrow \text { GAMs' phagocytic } \\
\text { activity }\end{array}$ & $\begin{array}{l}\uparrow \text { IFN } \gamma \text { and IL-12 } \\
\text { intratumoral levels } \\
\text { induced by rAAV2. }\end{array}$ & $\begin{array}{l}\downarrow \text { Tumor growth } \\
\uparrow \text { Survival }\end{array}$ & {$[61,62]$} \\
\hline $\begin{array}{l}\text { miR-142-6p } \\
\text { Investigational }\end{array}$ & $\begin{array}{l}\text { Biologic } \\
\text { (Synthetic oligonucle- } \\
\text { otide) }\end{array}$ & mRNA & $\begin{array}{l}\uparrow \text { GAMs' tumor } \\
\text { infiltration } \\
\uparrow \text { GAMs' antitumor } \\
\text { immune activation }\end{array}$ & & $\begin{array}{l}\downarrow \text { Tumor growth } \\
\uparrow \text { Survival }\end{array}$ & {$[63]$} \\
\hline $\begin{array}{l}\mathbf{X 7 A b} \\
\text { Investigational }\end{array}$ & $\begin{array}{l}\text { Biologic } \\
\text { (single-chain anti- } \\
\text { body) }\end{array}$ & ACKR3 / CXCR7 & $\begin{array}{l}\uparrow \text { GAMs' antitumor } \\
\text { immune activation }\end{array}$ & $\begin{array}{l}\text { Increased therapeu- } \\
\text { tic effects of TMZ }\end{array}$ & $\begin{array}{l}\downarrow \text { Tumor growth } \\
\uparrow \text { Survival }\end{array}$ & [68] \\
\hline
\end{tabular}




\begin{tabular}{|c|c|c|c|c|c|c|}
\hline \multicolumn{7}{|l|}{ Clinical evidence } \\
\hline $\begin{array}{l}\text { Nivolumab } \\
\text { FDA and EMA approved }\end{array}$ & $\begin{array}{l}\text { Biologic } \\
(\mathrm{mAb})\end{array}$ & \multicolumn{2}{|l|}{ PD-1 } & Phase III & \multicolumn{2}{|c|}{$\begin{array}{l}\text { No superior survival [19] } \\
\text { vs. bevacizumab }\end{array}$} \\
\hline $\begin{array}{l}\text { BLZ945/PDRO01 } \\
\text { Investigational }\end{array}$ & $\begin{array}{l}\text { Small MW com- } \\
\text { pound/ } \\
\text { Biologic (mAb) }\end{array}$ & CSF-1R/PD1 & & Phase I/II & & $\begin{array}{l}\text { Clinicaltri- } \\
\text { als. } \\
\text { gov }\end{array}$ \\
\hline $\begin{array}{l}\text { PLX3397 } \\
\text { Investigational }\end{array}$ & Small MW compound & CSF-1R & $\begin{array}{l}\downarrow \text { lba1+ cells } \\
\text { within the } \\
\text { tumors }\end{array}$ & $\begin{array}{l}\text { Phase II } \\
\text { (recurrent } \\
\text { glioblastoma) }\end{array}$ & $\begin{array}{l}\text { No significant } \\
\text { effects on PFS com- } \\
\text { pared with histori- } \\
\text { cal controls }\end{array}$ & [38] \\
\hline $\begin{array}{l}\text { Cilengitide } \\
\text { Investigational } \\
\text { (in combination with } \\
\text { TMZ) }\end{array}$ & $\begin{array}{l}\text { Synthetic cyclic RGD } \\
\text { pentapeptide }\end{array}$ & $\begin{array}{l}\text { av } \beta 3 \text { and av } \beta 5 \\
\text { integrins }\end{array}$ & & Phase III & $\begin{array}{l}\text { No superior survival } \\
\text { vs. TMZ alone }\end{array}$ & {$[45,46]$} \\
\hline
\end{tabular}

In the table we reported the main features of drugs that interferes with biological functions of GAMs (name, characteristics and molecular target) together with the pharmacological actions on GAMs and the clinical outcomes on glioblastoma. Drugs are listed based on the level of evidence, i.e., preclinical (in vitro and in vivo) or clinical testing, according to the following criteria: (1) approved for clinical use (1st, small molecular weight compounds, 2nd biologics); and (2) investigational drugs (1st, small molecular weight compounds, 2nd biologics). $\uparrow$ : increased; $\downarrow$ : reduced. AmpB: amphotericin B; ARG1: arginase 1; BBB: blood-brain-barrier; CD: cluster of differentiation; CCL2: chemokine (C-C motif) ligand 2; CCR5: C-C chemokine receptor type 5; CHA: chlorogenic acid (5-caffeoylquinic acid); CsA: cyclosporine A; CSFs: colony stimulating factors; CSF1: macrophage colony stimulating factor; CSF1R: M-CSF receptor; CSF2R: GM-CSF receptor; CSF2: granulocyte/macrophage colony stimulating factor; GAMs: glioma associated microglia/macrophages; GM-CSF: granulocyte/ macrophage colony stimulating factor; GSCs: glioblastoma cancer stem cells; JAK: Janus kinase; HGF: hepatocyte growth factor; Iba1: ionized calcium-binding adapter molecule 1, i.e., a specific myeloid lineage marker; IFN $\gamma$ : interferon $\gamma$; IL: interleukin; iNOS: inducible nitric oxide synthase; mAb: monoclonal antibody; MAPK: mitogen-activated protein kinase; MCP: monocyte chemotactic protein; M-CSF: macrophage colony stimulating factor; MDSCs: myeloid-derived suppressor cells; mTOR: mechanistic target of rapamycin kinase; MMP: matrix metalloprotease; miRNA, or miR: microRNA; NFAT1: nuclear factor of activated T cells; MW: molecular weight; PFS: progression free survival; PG: prostaglandin; PI3K: phosphoinositide 3-kinase; PD-1: programmed death-1; rAAV2: recombinant adeno-associated viral vector; SDF-1: stromal-derived factor-1; SPP1: osteopontin; STAT: signal transducer and activator of transcription; TGF $\beta$ : transforming growth factor $\beta$; TMZ: temozolomide; TOPO-II: topoisomerase-II; TRAM-34: 1-(2-chlorophenyl) diphenylmethyl-1H-pyrazole; Tregs: regulatory T cells; VEGF-A: vascular endothelial growth factor-A; X7Ab: single chain antibody

eral strategies attempt to overcome this restriction such as improved drug formulation (i.e., nanoparticles or lipid based formulation), local drug delivery (including gene therapy ${ }^{[61,62]}$ ), or transient BBB permeabiliza$\operatorname{tion}^{[83,84]}$, to name a few. Among the above mentioned drugs, minocycline and rapamycin for example, have increased BBB penetration properties; and novel mTOR inhibitors with improved pharmacokinetic properties are also under development. It is possible to envision the use of pharmacological compounds, targeting GAMs' functions, as a complement to current available therapeutic approaches.

\section{DECLARATIONS}

\section{Authors' contributions}

Conceived the paper and wrote the primary draft: Dello Russo C

Contributed to the literature revision and manuscript editing: Cappoli $\mathrm{N}$

Read and approved the final manuscript: Dello Russo C, Cappoli N

\section{Availability of data and materials}

Not applicable.

\section{Financial support and sponsorship}

Research on GAMs has been in part funded by Fondi di Ateneo 2014-2016, grants awarded to DRC.

\section{Conflicts of interest}

All authors declared that there are no conflicts of interest. 


\section{Ethical approval and consent to participate}

Not applicable.

\section{Consent for publication}

Not applicable.

\section{Copyright}

(C) The Author(s) 2018.

\section{REFERENCES}

1. Glass R, Synowitz M. CNS macrophages and peripheral myeloid cells in brain tumours. Acta Neuropathol 2014;128:347-62.

2. Verhaak RG, Hoadley KA, Purdom E, Wang V, Qi Y, Wilkerson MD, Miller CR, Ding L, Golub T, Mesirov JP, Alexe G, Lawrence M, O'Kelly M, Tamayo P, Weir BA, Gabriel S, Winckler W, Gupta S, Jakkula L, Feiler HS, Hodgson JG, James CD, Sarkaria JN, Brennan C, Kahn A, Spellman PT, Wilson RK, Speed TP, Gray JW, Meyerson M, Getz G, Perou CM, Hayes DN; Cancer Genome Atlas Research Network. Integrated genomic analysis identifies clinically relevant subtypes of glioblastoma characterized by abnormalities in PDGFRA, IDH1, EGFR, and NF1. Cancer Cell 2010;17:98-110.

3. Beier CP, Kumar P, Meyer K, Leukel P, Bruttel V, Aschenbrenner I, Riemenschneider MJ, Fragoulis A, Rümmele P, Lamszus K, Schulz JB, Weis J, Bogdahn U, Wischhusen J, Hau P, Spang R, Beier D. The cancer stem cell subtype determines immune infiltration of glioblastoma. Stem Cells Dev 2012;21:2753-61.

4. Dello Russo C, Lisi L, Tentori L, Navarra P, Graziani G, Combs CK. Exploiting microglial functions for the treatment of glioblastoma. Curr Cancer Drug Targets 2017;17:267-81.

5. Arcuri C, Fioretti B, Bianchi R, Mecca C, Tubaro C, Beccari T, Franciolini F, Giambanco I, Donato R. Microglia-glioma cross-talk: a two way approach to new strategies against glioma. Front Biosci (Landmark Ed) 2017;22:268-309.

6. Annovazzi L, Mellai M, Bovio E, Mazzetti S, Pollo B, Schiffer D. Microglia immunophenotyping in gliomas. Oncol Lett 2018;15:9981006.

7. Lisi L, Ciotti GM, Braun D, Kalinin S, Currò D, Dello Russo C, Coli A, Mangiola A, Anile C, Feinstein DL, Navarra P. Expression of iNOS, CD163 and ARG-1 taken as M1 and M2 markers of microglial polarization in human glioblastoma and the surrounding normal parenchyma. Neurosci Lett 2017;645:106-12.

8. Brandenburg S, Müller A, Turkowski K, Radev YT, Rot S, Schmidt C, Bungert AD, Acker G, Schorr A, Hippe A, Miller K, Heppner FL, Homey B, Vajkoczy P. Resident microglia rather than peripheral macrophages promote vascularization in brain tumors and are source of alternative pro-angiogenic factors. Acta Neuropathol 2016;131:365-78.

9. Gabrusiewicz K, Ellert-Miklaszewska A, Lipko M, Sielska M, Frankowska M, Kaminska B. Characteristics of the alternative phenotype of microglia/macrophages and its modulation in experimental gliomas. PLoS One 2011;6:e23902.

10. Zhai H, Heppner FL, Tsirka SE. Microglia/macrophages promote glioma progression. Glia 2011;59:472-85.

11. Markovic DS, Vinnakota K, Chirasani S, Synowitz M, Raguet H, Stock K, Sliwa M, Lehmann S, Kälin R, van Rooijen N, Holmbeck K, Heppner FL, Kiwit J, Matyash V, Lehnardt S, Kaminska B, Glass R, Kettenmann H. Gliomas induce and exploit microglial MT1-MMP expression for tumor expansion. Proc Natl Acad Sci U S A 2009;106:12530-5.

12. Sliwa M, Markovic D, Gabrusiewicz K, Synowitz M, Glass R, Zawadzka M, Wesolowska A, Kettenmann H, Kaminska B. The invasion promoting effect of microglia on glioblastoma cells is inhibited by cyclosporin A. Brain 2007;130:476-89.

13. Wick W, Osswald M, Wick A, Winkler F. Treatment of glioblastoma in adults. Ther Adv Neurol Disord 2018;11:1756286418790452.

14. Vairano M, Graziani G, Tentori L, Tringali G, Navarra P, Dello Russo C. Primary cultures of microglial cells for testing toxicity of anticancer drugs. Toxicol Lett 2004;148:91-4.

15. Castro BA, Flanigan P, Jahangiri A, Hoffman D, Chen W, Kuang R, De Lay M, Yagnik G, Wagner JR, Mascharak S, Sidorov M, Shrivastav S, Kohanbash G, Okada H, Aghi MK. Macrophage migration inhibitory factor downregulation: a novel mechanism of resistance to anti-angiogenic therapy. Oncogene 2017;36:3749-59.

16. Gabrusiewicz K, Liu D, Cortes-Santiago N, Hossain MB, Conrad CA, Aldape KD, Fuller GN, Marini FC, Alonso MM, Idoate MA, Gilbert MR, Fueyo J, Gomez-Manzano C. Anti-vascular endothelial growth factor therapy-induced glioma invasion is associated with accumulation of Tie2-expressing monocytes. Oncotarget 2014;5:2208-20.

17. Piao Y, Liang J, Holmes L, Zurita AJ, Henry V, Heymach JV, de Groot JF. Glioblastoma resistance to anti-VEGF therapy is associated with myeloid cell infiltration, stem cell accumulation, and a mesenchymal phenotype. Neuro Oncol 2012;14:1379-92.

18. Stafford JH, Hirai T, Deng L, Chernikova SB, Urata K, West BL, Brown JM. Colony stimulating factor 1 receptor inhibition delays recurrence of glioblastoma after radiation by altering myeloid cell recruitment and polarization. Neuro Oncol 2016;18:797-806.

19. Kurz SC, Wen PY. Quo vadis-do immunotherapies have a role in glioblastoma? Curr Treat Options Neurol 2018;20:14.

20. Lucca LE, Hafler DA. Co-inhibitory blockade while preserving tolerance: checkpoint inhibitors for glioblastoma. Immunol Rev 2017;276:9-25.

21. Kamran N, Chandran M, Lowenstein PR, Castro MG. Immature myeloid cells in the tumor microenvironment: implications for immunotherapy. Clin Immunol 2018;189:34-42.

22. Badie B, Schartner J, Klaver J, Vorpahl J. In vitro modulation of microglia motility by glioma cells is mediated by hepatocyte growth factor/scatter factor. Neurosurgery 1999;44:1077-82; discussion 1082-3.

23. Komohara Y, Ohnishi K, Kuratsu J, Takeya M. Possible involvement of the M2 anti-inflammatory macrophage phenotype in growth of 
human gliomas. J Pathol 2008;216:15-24.

24. Sielska M, Przanowski P, Wylot B, Gabrusiewicz K, Maleszewska M, Kijewska M, Zawadzka M, Kucharska J, Vinnakota K, Kettenmann H, Kotulska K, Grajkowska W, Kaminska B. Distinct roles of CSF family cytokines in macrophage infiltration and activation in glioma progression and injury response. J Pathol 2013;230:310-21.

25. Hamilton JA. Colony-stimulating factors in inflammation and autoimmunity. Nat Rev Immunol 2008;8:533-44.

26. Okada M, Saio M, Kito Y, Ohe N, Yano H, Yoshimura S, Iwama T, Takami T. Tumor-associated macrophage/microglia infiltration in human gliomas is correlated with MCP-3, but not MCP-1. Int J Oncol 2009;34:1621-7.

27. Zhu X, Fujita M, Snyder LA, Okada H. Systemic delivery of neutralizing antibody targeting CCL2 for glioma therapy. J Neurooncol 2011;104:83-92.

28. Wang SC, Hong JH, Hsueh C, Chiang CS. Tumor-secreted SDF-1 promotes glioma invasiveness and TAM tropism toward hypoxia in a murine astrocytoma model. Lab Invest 2012;92:151-62.

29. Yu K, Youshani AS, Wilkinson FL, O’Leary C, Cook P, Laaniste L, Liao A, Mosses D, Waugh C, Shorrock H, Pathmanaban O, Macdonald A, Kamaly-Asl I, Roncaroli F, Bigger BW. A nonmyeloablative chimeric mouse model accurately defines microglia and macrophage contribution in glioma. Neuropathol Appl Neurobiol 2018; doi: 10.1111/nan.12489.

30. Gabrusiewicz K, Rodriguez B, Wei J, Hashimoto Y, Healy LM, Maiti SN, Thomas G, Zhou S, Wang Q, Elakkad A, Liebelt BD, Yaghi NK, Ezhilarasan R, Huang N, Weinberg JS, Prabhu SS, Rao G, Sawaya R, Langford LA, Bruner JM, Fuller GN, Bar-Or A, Li W, Colen RR, Curran MA, Bhat KP, Antel JP, Cooper LJ, Sulman EP, Heimberger AB. Glioblastoma-infiltrated innate immune cells resemble M0 macrophage phenotype. JCI Insight 2016;1:pii: e85841.

31. Durnian JM, Stewart RM, Tatham R, Batterbury M, Kaye SB. Cyclosporin-A associated malignancy. Clin Ophthalmol 2007;1:421-30.

32. Yilaz Susluer S, Biray Avci C, Dodurga Y, Ozlem Dogan Sigva Z, Oktar N, Gunduz C. Downregulation of miR-195 via cyclosporin A in human glioblastoma cells. J BUON 2015;20:1337-40.

33. Hui W, Yuntao L, Lun L, WenSheng L, ChaoFeng L, HaiYong H, Yueyang B. MicroRNA-195 inhibits the proliferation of human glioma cells by directly targeting cyclin D1 and cyclin E1. PLoS One 2013;8:e54932.

34. Zhang QQ, Xu H, Huang MB, Ma LM, Huang QJ, Yao Q, Zhou H, Qu LH. MicroRNA-195 plays a tumor-suppressor role in human glioblastoma cells by targeting signaling pathways involved in cellular proliferation and invasion. Neuro Oncol 2012;14:278-87.

35. Tie X, Han S, Meng L, Wang Y, Wu A. NFAT1 is highly expressed in, and regulates the invasion of, glioblastoma multiforme cells. PLoS One 2013;8:e66008.

36. Pyonteck SM, Akkari L, Schuhmacher AJ, Bowman RL, Sevenich L, Quail DF, Olson OC, Quick ML, Huse JT, Teijeiro V, Setty M, Leslie CS, Oei Y, Pedraza A, Zhang J, Brennan CW, Sutton JC, Holland EC, Daniel D, Joyce JA. CSF-1R inhibition alters macrophage polarization and blocks glioma progression. Nat Med 2013;19:1264-72.

37. Sadahiro H, Kang KD, Gibson JT, Minata M, Yu H, Shi J, Chhipa R, Chen Z, Lu S, Simoni Y, Furuta T, Sabit H, Zhang S, Bastola S, Yamaguchi S, Alsheikh H, Komarova S, Wang J, Kim SH, Hambardzumyan D, Lu X, Newell EW, DasGupta B, Nakada M, Lee LJ, Nabors B, Norian LA, Nakano I. Activation of the receptor tyrosine kinase AXL regulates the immune microenvironment in glioblastoma. Cancer Res 2018;78:3002-13.

38. Butowski N, Colman H, De Groot JF, Omuro AM, Nayak L, Wen PY, Cloughesy TF, Marimuthu A, Haidar S, Perry A, Huse J, Phillips J, West BL, Nolop KB, Hsu HH, Ligon KL, Molinaro AM, Prados M. Orally administered colony stimulating factor 1 receptor inhibitor PLX3397 in recurrent glioblastoma: an Ivy Foundation Early Phase Clinical Trials Consortium phase II study. Neuro Oncol 2016;18:557-64

39. Chen Z, Feng X, Herting CJ, Garcia VA, Nie K, Pong WW, Rasmussen R, Dwivedi B, Seby S, Wolf SA, Gutmann DH, Hambardzumyan D. Cellular and molecular identity of tumor-associated macrophages in glioblastoma. Cancer Res 2017;77:2266-78.

40. Salacz ME, Kast RE, Saki N, Brüning A, Karpel-Massler G, Halatsch ME. Toward a noncytotoxic glioblastoma therapy: blocking MCP1 with the MTZ Regimen. Onco Targets Ther 2016;9:2535-45.

41. Bangalore Kumar A, Maus R, Markovic SN. Pharmacologic modulation of human immunity in the era of immuno-oncology: something old, something new. Mayo Clin Proc 2018;93:917-36.

42. Shah S, Dunn-Pirio A, Luedke M, Morgenlander J, Skeen M, Eckstein C. Nivolumab-induced autoimmune encephalitis in two patients with lung adenocarcinoma. Case Rep Neurol Med 2018;2018:2548528.

43. Martinot M, Ahle G, Petrosyan I, Martinez C, Gorun DM, Mohseni-Zadeh M, Fafi-Kremer S, Tebacher-Alt M. Progressive multifocal leukoencephalopathy after treatment with nivolumab. Emerg Infect Dis 2018;24:1594-96.

44. Zhou W, Ke SQ, Huang Z, Flavahan W, Fang X, Paul J, Wu L, Sloan AE, McLendon RE, Li X, Rich JN, Bao S. Periostin secreted by glioblastoma stem cells recruits M2 tumour-associated macrophages and promotes malignant growth. Nat Cell Biol 2015;17:170-82.

45. Stupp R, Hegi ME, Gorlia T, Erridge SC, Perry J, Hong YK, Aldape KD, Lhermitte B, Pietsch T, Grujicic D, Steinbach JP, Wick W, Tarnawski R, Nam DH, Hau P, Weyerbrock A, Taphoorn MJ, Shen CC, Rao N, Thurzo L, Herrlinger U, Gupta T, Kortmann RD, Adamska K, McBain C, Brandes AA, Tonn JC, Schnell O, Wiegel T, Kim CY, Nabors LB, Reardon DA, van den Bent MJ, Hicking C, Markivskyy A, Picard M, Weller M; European Organisation for Research and Treatment of Cancer (EORTC); Canadian Brain Tumor Consortium; CENTRIC study team. Cilengitide combined with standard treatment for patients with newly diagnosed glioblastoma with methylated MGMT promoter (CENTRIC EORTC 26071-22072 study): a multicentre, randomised, open-label, phase 3 trial. Lancet Oncol 2014; $15: 1100-8$

46. Stupp R, Picard M, Weller M. Does cilengitide deserve another chance? Authors' reply. Lancet Oncol 2014;15:e585-6.

47. Ellert-Miklaszewska A, Wisniewski P, Kijewska M, Gajdanowicz P, Pszczolkowska D, Przanowski P, Dabrowski M, Maleszewska M, Kaminska B. Tumour-processed osteopontin and lactadherin drive the protumorigenic reprogramming of microglia and glioma progression. Oncogene 2016;35:6366-77.

48. Li W, Graeber MB. The molecular profile of microglia under the influence of glioma. Neuro Oncol 2012;14:958-78.

49. Wu A, Wei J, Kong LY, Wang Y, Priebe W, Qiao W, Sawaya R, Heimberger AB. Glioma cancer stem cells induce immunosuppressive 
macrophages/microglia. Neuro Oncol 2010;12:1113-25.

50. Hamill RJ. Amphotericin B formulations: a comparative review of efficacy and toxicity. Drugs 2013;73:919-34.

51. Mihu MR, Pattabhi R, Nosanchuk JD. The impact of antifungals on toll-like receptors. Front Microbiol 2014;5:99.

52. Sarkar S, Yong VW. The battle for the brain: brain tumor-initiating cells vs. microglia/macrophages. Oncoimmunology 2014;3:e28047.

53. Yang R, Sarkar S, Korchinski DJ, Wu Y, Yong VW, Dunn JF. MRI monitoring of monocytes to detect immune stimulating treatment response in brain tumor. Neuro Oncol 2017;19:364-71.

54. Saxton RA, Sabatini DM. mTOR signaling in growth, metabolism, and disease. Cell 2017;168:960-76.

55. Ryskalin L, Limanaqi F, Biagioni F, Frati A, Esposito V, Calierno MT, Lenzi P, Fornai F. The emerging role of m-TOR up-regulation in brain Astrocytoma. Histol Histopathol 2017;32:413-31.

56. Chiarini F, Evangelisti C, McCubrey JA, Martelli AM. Current treatment strategies for inhibiting mTOR in cancer. Trends Pharmacol Sci 2015;36:124-35.

57. Lin F, Buil L, Sherris D, Beijnen JH, van Tellingen O. Dual mTORC1 and mTORC2 inhibitor Palomid 529 penetrates the blood-brain barrier without restriction by ABCB1 and ABCG2. Int J Cancer 2013;133:1222-33.

58. Lisi L, Stigliano E, Lauriola L, Navarra P, Dello Russo C. Proinflammatory-activated glioma cells induce a switch in microglial polarization and activation status, from a predominant M2b phenotype to a mixture of M1 and M2a/B polarized cells. ASN Neuro 2014;6:171-83.

59. Laudati E, Currò D, Navarra P, Lisi L. Blockade of CCR5 receptor prevents M2 microglia phenotype in a microglia-glioma paradigm. Neurochem Int 2017;108:100-8

60. Grimaldi A, D’Alessandro G, Golia MT, Grössinger EM, Di Angelantonio S, Ragozzino D, Santoro A, Esposito V, Wulff H, Catalano M, Limatola C. KCa3.1 inhibition switches the phenotype of glioma-infiltrating microglia/macrophages. Cell Death Dis 2016;7:e2174.

61. Chiu TL, Peng CW, Wang MJ. Enhanced anti-glioblastoma activity of microglia by AAV2-mediated IL-12 through TRAIL and phagocytosis in vitro. Oncol Rep 2011;25:1373-80.

62. Chiu TL, Wang MJ, Su CC. The treatment of glioblastoma multiforme through activation of microglia and TRAIL induced by rAAV2mediated IL-12 in a syngeneic rat model. J Biomed Sci 2012;19:45.

63. Xu S, Wei J, Wang F, Kong LY, Ling XY, Nduom E, Gabrusiewicz K, Doucette T, Yang Y, Yaghi NK, Fajt V, Levine JM, Qiao W, Li XG, Lang FF, Rao G, Fuller GN, Calin GA, Heimberger AB. Effect of miR-142-3p on the M2 macrophage and therapeutic efficacy against murine glioblastoma. J Natl Cancer Inst 2014;106:pii: dju162.

64. Mercurio L, Ajmone-Cat MA, Cecchetti S, Ricci A, Bozzuto G, Molinari A, Manni I, Pollo B, Scala S, Carpinelli G, Minghetti L. Targeting CXCR4 by a selective peptide antagonist modulates tumor microenvironment and microglia reactivity in a human glioblastoma model. J Exp Clin Cancer Res 2016;35:55.

65. Zeiner PS, Preusse C, Blank AE, Zachskorn C, Baumgarten P, Caspary L, Braczynski AK, Weissenberger J, Bratzke H, Reiß S, Pennartz S, Winkelmann R, Senft C, Plate KH, Wischhusen J, Stenzel W, Harter PN, Mittelbronn M. MIF receptor CD74 is restricted to microglia/ macrophages, associated with a M1-polarized immune milieu and prolonged patient survival in gliomas. Brain Pathol 2015;25:491-504.

66. Gravina GL, Mancini A, Mattei C, Vitale F, Marampon F, Colapietro A, Rossi G, Ventura L, Vetuschi A, Di Cesare E, Fox JA, Festuccia C. Enhancement of radiosensitivity by the novel anticancer quinolone derivative vosaroxin in preclinical glioblastoma models. Oncotarget 2017;8:29865-86.

67. Xue N, Zhou Q, Ji M, Jin J, Lai F, Chen J, Zhang M, Jia J, Yang H, Zhang J, Li W, Jiang J, Chen X. Chlorogenic acid inhibits glioblastoma growth through repolarizating macrophage from M2 to M1 phenotype. Sci Rep 2017;7:39011.

68. Salazar N, Carlson JC, Huang K, Zheng Y, Oderup C, Gross J, Jang AD, Burke TM, Lewén S, Scholz A, Huang S, Nease L, Kosek J, Mittelbronn M, Butcher EC, Tu H, Zabel BA. A chimeric antibody against ACKR3/CXCR7 in combination with TMZ activates immune responses and extends survival in mouse GBM models. Mol Ther 2018;26:1354-65.

69. Könnecke H, Bechmann I. The role of microglia and matrix metalloproteinases involvement in neuroinflammation and gliomas. Clin Dev Immunol 2013;2013:914104.

70. Coniglio SJ, Eugenin E, Dobrenis K, Stanley ER, West BL, Symons MH, Segall JE. Microglial stimulation of glioblastoma invasion involves epidermal growth factor receptor (EGFR) and colony stimulating factor 1 receptor (CSF-1R) signaling. Mol Med 2012;18:51927.

71. Markovic DS, Glass R, Synowitz M, Rooijen Nv, Kettenmann H. Microglia stimulate the invasiveness of glioma cells by increasing the activity of metalloprotease-2. J Neuropathol Exp Neurol 2005;64:754-62.

72. Chou J, Chan MF, Werb Z. Metalloproteinases: a functional pathway for myeloid cells. Microbiol Spectr 2016; doi: 10.1128/microbiolspec.MCHD-0002-2015.

73. Rao JS. Molecular mechanisms of glioma invasiveness: the role of proteases. Nat Rev Cancer 2003;3:489-501.

74. Guo P, Imanishi Y, Cackowski FC, Jarzynka MJ, Tao HQ, Nishikawa R, Hirose T, Hu B, Cheng SY. Up-regulation of angiopoietin-2, matrix metalloprotease-2, membrane type 1 metalloprotease, and laminin 5 gamma 2 correlates with the invasiveness of human glioma. Am J Pathol 2005; 166:877-90.

75. Hu F, Ku MC, Markovic D, a Dzaye OD, Lehnardt S, Synowitz M, Wolf SA, Kettenmann H. Glioma-associated microglial MMP9 expression is upregulated by TLR2 signaling and sensitive to minocycline. Int J Cancer 2014;135:2569-78.

76. Markovic DS, Vinnakota K, van Rooijen N, Kiwit J, Synowitz M, Glass R, Kettenmann H. Minocycline reduces glioma expansion and invasion by attenuating microglial MT1-MMP expression. Brain Behav Immun 2011;25:624-8.

77. Yongjun Y, Shuyun H, Lei C, Xiangrong C, Zhilin Y, Yiquan K. Atorvastatin suppresses glioma invasion and migration by reducing microglial MT1-MMP expression. J Neuroimmunol 2013;260:1-8.

78. Jacobs VL, Landry RP, Liu Y, Romero-Sandoval EA, De Leo JA. Propentofylline decreases tumor growth in a rodent model of glioblastoma multiforme by a direct mechanism on microglia. Neuro Oncol 2012;14:119-31.

79. Zhao D, Alizadeh D, Zhang L, Liu W, Farrukh O, Manuel E, Diamond DJ, Badie B. Carbon nanotubes enhance CpG uptake and poten- 
tiate antiglioma immunity. Clin Cancer Res 2011;17:771-82.

80. Zhang F, Mastorakos P, Mishra MK, Mangraviti A, Hwang L, Zhou J, Hanes J, Brem H, Olivi A, Tyler B, Kannan RM. Uniform brain tumor distribution and tumor associated macrophage targeting of systemically administered dendrimers. Biomaterials 2015;52:507-16.

81. Osterberg N, Ferrara N, Vacher J, Gaedicke S, Niedermann G, Weyerbrock A, Doostkam S, Schaefer HE, Plate KH, Machein MR. Decrease of VEGF-A in myeloid cells attenuates glioma progression and prolongs survival in an experimental glioma model. Neuro Oncol 2016;18:939-49.

82. Miyauchi JT, Chen D, Choi M, Nissen JC, Shroyer KR, Djordevic S, Zachary IC, Selwood D, Tsirka SE. Ablation of Neuropilin 1 from glioma-associated microglia and macrophages slows tumor progression. Oncotarget 2016;7:9801-14.

83. Juratli TA, Schackert G, Krex D. Current status of local therapy in malignant gliomas--a clinical review of three selected approaches. Pharmacol Ther 2013;139:341-58.

84. van Tellingen O, Yetkin-Arik B, de Gooijer MC, Wesseling P, Wurdinger T, de Vries HE. Overcoming the blood-brain tumor barrier for effective glioblastoma treatment. Drug Resist Updat 2015;19:1-12. 